\title{
Nadzór Prezesa Rady Ministrów nad samorządem terytorialnym
}

\author{
Ryszard P. Krawczyk \\ Uniwersytet Łódzki, Wydział Prawa i Administracji \\ Katedra Prawa Konstytucyjnego
}

1. Zgodnie z art. 171 ust. 2 Konstytucji Rzeczypospolitej Polskiej ${ }^{1}$ organami $^{2}$ nadzoru nad działalnością jednostek samorządu terytorialnego są Prezes Rady Ministrów i wojewodowie, a w zakresie spraw finansowych regionalne izby obrachunkowe. Sformułowanie konstytucyjne determinuje katalog podmiotów, które mogą występować jako organy nadzoru wobec samorządu terytorialnego. W świetle art. 171 ust. 1 Konstytucji RP działalność samorządu terytorialnego podlega nadzorowi z punktu widzenia legalności. Powstaje pytanie, czy dopuszczalne jest w kontekście sformułowania konstytucyjnego wyodrębnienie ustawowe jakichś innych organów, które sprawowałyby nadzór nad samorządem terytorialnym? Trzeba zająć tu zdecydowanie stanowisko o niedopuszczalności rozszerzania katalogu organów nadzoru wykonującego tę czynność weryfikacyjną wobec samorządu. Konstytucyjnie katalog organów nadzoru wobec samorządu został zamknięty i niedopuszczalne byłoby jego rozszerzanie w drodze ustawowej².

2. Nadzór zawsze będzie oznaczał wkroczenie uprawnionego organu w sferę działań samorządu, która charakteryzuje się większym (zadania własne) lub mniejszym zakresem samodzielności. W warunkach polskich, determinowanych postanowieniami Konstytucji RP oraz ustawami dotyczącymi pozycji ustrojowej samorządu terytorialnego, samodzielność ta może występować na różnych płaszczyznach. Samodzielność samorządu terytorialnego charakteryzuje się wielopłaszczyznowością oraz przejawia się w różnych aspektach jego funkcjonowania. Analizując samodzielność samorządu z punktu widzenia norm konstytucyjnych należy zwrócić uwagę, że:

- w świetle art. 169 Konstytucji RP samorząd terytorialny ma prawo do kształtowania swego ustroju wewnętrznego;

- w świetle art. 167 Konstytucji samorząd terytorialny posiada samodzielność finansową, która determinuje wykonywanie zadań publicznych we własnym imieniu i na własną odpowiedzialność;

1 Dz.U. z 1997 r., nr 78, poz. 483; z 2001 r., nr 28, poz. 319; z 2006 r., nr 200, poz. 1471 oraz z 2009 r., nr 114, poz. 946.

2 Por. B. Banaszak, Konstytucja Rzeczypospolitej Polskiej. Komentarz, Warszawa 2009, s. 768. 
- na podstawie art. 168 Konstytucji samorząd terytorialny wyposażono w samodzielność podatkową, która polega na stanowieniu podatków i opłat lokalnych w zakresie określonym ustawą;

- art. 165 ust. 1 Konstytucji statuuje samodzielność majątkową samorządu; jednostki samorządu terytorialnego posiadają osobowość prawną oraz przysługuje im prawo własności i inne prawa majątkowe;

- art. 163 i 166 Konstytucji wyposażają samorząd terytorialny w samodzielność publicznoprawną, co daje mu możliwość wykonywania zadań publicznych ${ }^{3}$.

Doktryna prawa rozróżnia ponadto samodzielność samorządu terytorialnego o charakterze publicznoprawnym i prywatnoprawnym ${ }^{4}$. Wskazuje się także na niezależność wobec innych organów, szczególnie organów administracji rządowej, jak również niezależność poszczególnych rodzajów samorządu terytorialnego wobec siebie ${ }^{5}$.

3. Pojęcie nadzoru $\mathrm{w}$ polskiej doktrynie prawnej oraz porządku prawnym występuje wielokrotnie - lecz nigdzie nie znajdziemy jego wyczerpującej definicji. Wydaje się, że w polskim prawie pojęcie nadzoru należy budować w oparciu o konkretne przepisy, które regulują nadzór ${ }^{6}$. Na ogół dokonuje się rozróżnienia między kontrolą i nadzorem. Przez tę pierwszą rozumie się możliwość wpływania na zachowanie się ludzi, tzw. sterowanie społeczne lub możliwość dokonywania porównania określonego stanu rzeczy, będącego przedmiotem badania, z występującymi $\mathrm{w}$ danej sytuacji standardami prawnymi oraz dokonywanie określonych czynności pokontrolnych $\mathrm{w}$ wyniku poczynionych ustaleń ${ }^{7}$. Interesujący nas nadzór ma niewątpliwie szerszy zakres, jest postacią kwalifikowanej kontroli i jego istotą są uprawnienia władcze wobec podmiotu nadzorowanego. Kontrowersje doktrynalne dotyczą przede wszystkim odpowiedzi na pytanie: czy nadzór jest expost oddziaływaniem weryfikacyjnym, czy też ma ex ante charakter prewencyjny? Z punktu widzenia psychologicznego nadzór obejmuje oba typy oddziaływania. Dotyczy on działalności określonych organów, ale personifikowanych określonym substratem ludzkim.

Element władczości występujący w rozstrzygnięciach nadzorczych jest w doktrynie różnie nazywany. Dla W. Dawidowicza nadzór jest „wpływem”. To znaczy, że „nadzór oznacza, najogólniej rzecz biorąc, prawną możliwość wpływania przez organ administracji państwowej na działalność podporządkowanych organów

3 B. Dolnicki, Samorzad terytorialny, Warszawa 2009, s. 57.

4 A. Pawłyta, Samodzielność - pojęcie i granice, [w:] J. Sługocki (red.), Samorząd terytorialny w Polsce i w Europie. Doświadczenia i dylematy dalszego rozwoju, Bydgoszcz 2009, s. 103.

5 Ibidem, s. 105.

6 Tak: J. Boć, M. Miemiec, Organizacja prawna administracji, [w:] J. Boć (red.), Prawo administracyjne, Wrocław 1993, s. 140.

7 Patrz: J. Wróblewski, Kontrola w państwie i jej aksjologia (pojęcia podstawowe), „Acta Universitatis Lodziensis. Folia luridica" 1981, nr 6, s. 103-104. 
lub instytucji”". Podobnie w kategoriach „wpływania” należy umieścić poglądy M. Wierzbowskiego, dla którego uprawnienia nadzorcze to tyle, co prawo do kontroli wraz z możliwością wiążącego wpływania na organy czy instytucje nadzorowane ${ }^{9}$. Z kolei L. Bar wskazywał, że: „w każdym przypadku nadzoru występuje wspólny element, mianowicie prawo władczego oddziaływania na nadzorowany podmiot, ale w różnych granicach, zależnych od konkretnych przepisów prawnych" ${ }^{10}$. Z. Rybicki w rozważaniach nad istotą nadzoru używa terminu „władcze wkroczenie” i stwierdza, że „nadzór polega na możliwości władczego wkroczenia w działalność jednostki nadzorowanej w celu przywrócenia stanu zgodnego z prawem lub zasadniczą linią polityki państwa" ${ }^{11}$. Z „władczym wkraczaniem” nadzór łączy też Z. Niewiadomski, podkreślając, iż jest on „nieodłącznie związany z zdecentralizowanym systemem organizacyjnym" ${ }^{\prime 2}$.

Dla J. Jeżewskiego nadzór oznacza „kompetencje nadzorczego organu administracji państwowej do ingerencji za pomocą określonych ściśle przez prawo środków i w określonych sytuacjach w działalność organu nadzorowanego"13. Występuje również w polskiej doktrynie prawnej grupa autorów, którzy jako element nadzoru wymieniają „kontrolę” lub też „kontrolę i władcze oddziaływanie”. J. Łętowski wskazywał, że „nadzór oznacza zwykle kontrolę podejmowaną z uwagi na zabezpieczenie przestrzegania prawa, kontrolę ex post połączoną z możliwością uchylenia kontrolowanych aktów”14. J. Starościak zauważał, że "nadzór zawsze obejmuje także kontrolę"15. Ten autor stał ponadto na stanowisku, że „organ nadzorujący nie tylko spostrzega i ocenia. On również w pewnym sensie współadministruje, odpowiada za wyniki działalności organizatorskiej organów podległych nadzorowi" ${ }^{16}$. Stanowisko to jest charakterystyczne dla okresu tzw. centralizmu demokratycznego w Polsce i, jak się wydaje, ma uzasadniać omnipotencję ówczesnej partii rządzącej.

Według B. Banaszaka nadzór to „działalność obejmująca kontrolę oraz kompetencję do merytorycznego korygowania działalności podmiotu poddanego nadzo-

8 W. Dawidowicz, Zagadnienia ustroju administracji państwowej w Polsce, Warszawa 1970, s. 35

9 M. Wierzbowski, [w:] L. Jastrzębski et al., Polskie prawo administracyjne, cz. I, Warszawa 1985, s. 46.

10 L. Bar, Elementy administracyjne w kierowaniu gospodarka narodowa, [w:] L. Bar (red.), Instytucje prawne w gospodarce narodowej (studia prawne), Warszawa 1981, s. 93.

11 Z. Rybicki, Nadzór i kontrola, [w:] Z. Rybicki, S. Piątek, Zarys prawa administracyjnego i nauki administracji, Warszawa 1984, s. 263.

12 Z. Niewiadomski, [w:] Wielka encyklopedia prawa, red. nacz. B. Hołyst, wyd. II, Warszawa 2005, s. 459.

13 J. Jeżewski, [w:] Encyklopedia prawa, wyd. II, Warszawa 2000, s. 498-499.

14 J. Łętowski, J. Szreniawski, Kontrola administracji, [w:] T. Rabska, J. Łętowski (red.), System prawa administracyjnego, t. III, Wrocław 1978, s. 353.

15 J. Starościak, Prawo administracyjne, wyd. V, Warszawa 1978, s. 349.

16 Ibidem. 
rowi” ${ }^{17}$. Współcześnie nadzór utożsamiany jest także z pewnym typem stosunku prawnego - administracja jest poddana obowiązującemu prawu, zatem stosunki w niej zachodzące są stosunkami prawnymi ${ }^{18}$.

W polskiej doktrynie prawa administracyjnego występują także rozbieżności na temat rodzajów nadzoru. J. Służewski wymienia: a) nadzór prewencyjny, którego istotą jest wkraczanie organu nadzoru jeszcze przed rozpoczęciem działalności przez organ nadzorowany i zapobieganie ewentualnym nieprawidłowościom; b) nadzór weryfikacyjny, polegający na weryfikowaniu i uchylaniu decyzji organu nadzorowanego; c) nadzór represyjny, który polega na wyciągnięciu konsekwencji w stosunku do organu podejmującego niewłaściwe - sprzeczne z prawem - działanie $^{19}$. M. Tarka zauważając rozbieżności doktrynalne, wyróżnia: a) nadzór prewencyjny, którego istota zmierza do zapobiegania nieprawidłowej działalności jednostki nadzorowanej; b) nadzór weryfikacyjny (korygujący, represyjny), zmierzający do przywrócenia prawidłowości w już podejmowanej działalności; c) nadzór pozytywny, mający za zadanie przeciwdziałanie nieprawidłowościom, który $\mathrm{w}$ istocie służy przymusowemu wykonaniu obowiązków przez jednostkę nadzorowaną; d) nadzór kształtujący, wpływający na zmianę sytuacji prawnej jednostki nadzorowanej poprzez nałożenie obowiązków lub wydanie zakazu podejmowania działalności przez tę jednostkę ${ }^{20}$.

4. Zauważyć należy, że Konstytucja RP w art. 171 ust. 3 stwierdza, iż Sejm na wniosek Prezesa Rady Ministrów może rozwiązać organ stanowiący samorządu terytorialnego, jeżeli organ ten rażąco narusza Konstytucję lub ustawy. Sejmu nie zalicza się w doktrynie do organów nadzoru, przyjmując stanowisko, że jest tylko organem wyposażonym w uprawnienia nadzorcze. Ten rodzaj nadzoru jest nadzorem stricte politycznym, znanym już w okresie Polski Ludowej. Należy podkreślić, że ten drastyczny środek ingerencji nadzorczej mógł być uruchomiony wobec rady gminy, rady powiatu i sejmiku województwa do roku 2001 na podstawie zróżnicowanych kryteriów. Mogło to nastąpić w przypadku powtarzającego się naruszenia Konstytucji lub ustaw przez radę gminy; rażącego naruszenia Konstytucji lub ustaw przez radę powiatu lub też naruszenia Konstytucji lub rażącego albo wielokrotnego naruszenia ustaw przez sejmik województwa. Taka regulacja przyczyn rozwiązania przez Sejm organów stanowiących samorządu wyraźnie wskazywała, że najostrzejszemu rygorowi nadzorczemu podlegały sejmiki, zaś najłagodniejsze$\mathrm{mu}$ - rady powiatowe. Wielokrotne naruszenie Konstytucji lub ustaw przez radę

17 B. Banaszak, [w:] U. Kalina-Prasznik (red.), Encyklopedia prawa, wyd. II, Warszawa 2000, s. 497.

18 Zwraca na to uwagę D. Wacinkiewicz, Kontrola i nadzór w prawie komunalnym, Warszawa 2007, s. 199.

19 J. Służewski, Nadzór i kontrola, [w:] T. Bocheński, S. Gebert, J. Służewski, Rady narodowe i terenowe organy administracji państwowej, Warszawa 1977, s. 259-263.

20 M. Tarka, Istota prawna nadzoru w gospodarce państwowej, Poznań 1990, s. 14. 
powiatu nie było wystarczające do jej rozwiązania, jeżeli nie dało się udowodnić, że były to naruszenia rażące. Podjęcie przez Sejm uchwały o rozwiązaniu organu stanowiącego oznaczało równoczesne rozwiązanie wszystkich innych organów danej jednostki samorządu terytorialnego. $\mathrm{W}$ takiej sytuacji premier wyznaczał osobę upoważnioną do pełnienia funkcji organów gminy lub powiatu. W przypadku gminy czynił to na wniosek Ministerstwa Spraw Wewnętrznych i Administracji. Jeżeli Sejm rozwiązywał sejmik, to funkcje organów samorządu województwa miał przejmować wojewoda.

W obecnym stanie prawnym, kiedy organ wykonawczy gminy pochodzi z wyborów, bezpośrednich sankcje, które może stosować Sejm dotyczą wyłącznie organu stanowiącego gminy - art. 96 ustawy o samorządzie gminnym ${ }^{21}$ (dalej: u.s.g.).

Natomiast obecnie wobec sejmiku województwa (art. 84 ustawy o samorządzie województwa ${ }^{22}$ ) i rady powiatu (art. 83 ustawy o samorządzie powiatowym ${ }^{23}$ ) w przypadku powtarzającego się naruszenia Konstytucji lub ustaw (a więc co najmniej dwukrotnego) sankcja dotyczy rozwiązania zarówno organu stanowiącego, jak i wykonawczego, a osoba zastępująca te organy do czasu wyborów jest wyznaczana przez premiera na wniosek ministra właściwego do spraw administracji publicznej. Jeżeli powtarzającego się naruszenia Konstytucji lub ustaw dopuszcza się wójt lub zarząd powiatu albo zarząd województwa, to wojewoda ma obowiązek wezwania wójta do zaprzestania naruszeń, zaś w tym drugim przypadku dotyczącym zarządów wojewoda zwraca się do organu stanowiącego o zastosowanie niezbędnych środków. Jeżeli to wezwanie nie odnosi skutku, wojewoda za pośrednictwem ministra właściwego do spraw administracji publicznej występuje z wnioskiem do Prezesa Rady Ministrów o odwołanie wójta oraz o rozwiązanie zarządu powiatu lub zarządu województwa. W razie odwołania wójta lub rozwiązania zarządu, do czasu wyboru wójta lub nowego zarządu funkcję tę pełni osoba wyznaczona przez Prezesa Rady Ministrów. Orzeczenie Prezesa Rady Ministrów o rozwiązaniu/odwołaniu organu wykonawczego skutkuje dopiero $\mathrm{z}$ datą uprawomocnienia się. Rozwiązanie/odwołanie podlega bowiem sądowej kontroli dokonywanej przez sąd administracyjny w oparciu o kryterium legalności. W sytuacji, gdy organ wykonawczy zdecyduje się na zaskarżenie rozstrzygnięcia nadzorczego do sądu administracyjnego, a tak na ogół jest, będzie on mógł wykonywać swoje funkcje co najmniej do czasu uprawomocnienia się orzeczenia sądu ${ }^{24}$.

Należy zauważyć, że sankcja rozwiązania organu j.s.t. ma zastosowanie nie tylko, gdy naruszenia dokonywane są w uchwałach lub zarządzeniach. Środek ten może być zastosowany także, gdy naruszenie Konstytucji lub ustaw następuje poprzez

21 Tekst jedn. Dz.U. z 2013 r., poz. 594 ze zm.

22 Tekst jedn. Dz.U. z 2013 r., poz. 596 ze zm.

23 Tekst jedn. Dz.U. z 2013 r., poz. 595 ze zm.

24 G. Węgrzyn, Rozwiq̨zanie/odwołanie organów samorzq̨du terytorialnego jako środek nadzoru, „Samorząd Terytorialny” 2007, nr 7-8, s. 55. 
inne działania lub zaniechania tych organów ${ }^{25}$. Prezes Rady Ministrów, podejmując rozstrzygnięcie nadzorcze $w$ postaci ustanowienia zarządu komisarycznego, jest związany regułami postępowania administracyjnego. To one określają jego obowiązki w zakresie prowadzenia postępowania i orzekania. Zatem musi on przestrzegać m.in. zasady dochodzenia do prawdy obiektywnej (art. $7 \mathrm{kpa}$ ), jak również jest zobowiązany do należytego i wyczerpującego informowania stron o okolicznościach faktycznych i prawnych, które mogą mieć wpływ na ustalenie ich praw oraz obowiązków będących przedmiotem postępowania administracyjnego ${ }^{26}$.

5. Wyróżnienie przez Konstytucję RP trzech organów nadzoru: w zakresie spraw finansowych - regionalnych izb obrachunkowych, a w pozostałym zakresie Prezesa Rady Ministrów i wojewodów, musi prowadzić to postawienia pytania o podział kompetencji nadzorczych w ranach nadzoru ogólnego, wykonywanego przez premiera i wojewodów.

Wyodrębnienie w ramach nadzoru ogólnego dwóch organów: Prezesa Rady Ministrów i wojewodów, zmusza także do zastanowienia się nad zakresem i pierwszeństwem w wykonywaniu nadzoru przez każdy z nich. Wskazówki dla określenia zakresu kompetencji nadzorczych znajdziemy w ustawach ustrojowych dotyczących samorządu terytorialnego wszystkich trzech szczebli występujących w Polsce. Należy przyjąć, że kompetencje nadzorcze Prezesa Rady Ministrów są określone w odpowiednich artykułach ustaw samorządowych. Poza ich zakresem w ramach nadzoru ogólnego właściwym do wydawania rozstrzygnięć nadzorczych pozostaje wojewoda. Działalność nadzorcza Prezesa Rady Ministrów polega na stosowaniu tzw. środków nadzoru o charakterze personalnym ${ }^{27}$.

Ustawodawca do kompetencji nadzorczych Prezesa Rady Ministrów w art. 85 ustawy o samorządzie województwa, art. 84 ustawy o samorządzie powiatowym i art. 97 ustawy o samorządzie gminnym pozostawia przypadki drastyczne, które sprowadzają się do stanu nierokujacego szybkiej poprawy i przedłużającego się braku skuteczności w wykonywaniu zadań publicznych przez organy samorządu. Obie przesłanki muszą występować łącznie, co oznacza, że w tym przypadku nie chodzi wyłącznie o kryterium legalności, lecz o skuteczność działania organów samorządu $^{28}$. W takim przypadku Prezes Rady Ministrów na wniosek ministra właściwego do spraw administracji publicznej może zawiesić organy samorządu odpowiedniego szczebla i ustanowić zarząd komisaryczny na okres do lat 2, nie dłużej jednak niż do wyboru rady gminy i wójta na kolejną kadencję. W przypadku zarządu województwa zarząd komisaryczny może być ustanowiony na okres

25 Wyrok NSA w Warszawie z dnia 5 marca 2013 r., II OSK 135/13, LEX nr 1340168.

26 Tak: wyrok NSA z dnia 10 października 2012 r., II SA/Wa 1329/12, LEX nr 1258346.

27 Z. Kmieciak, M. Stahl, Akty nadzoru nad działalnościq samorządu terytorialnego, „Samorząd Terytorialny" 2001, nr 1-2, s. 111.

28 Z. Leoński, Nadzór nad samorzq̨dem terytorialnym w świetle ustawy z 8 marca 1990 r., „Państwo i Prawo" 1990, nr 12, s. 52-60. 
analogiczny, nie dłużej jednak niż do wyboru zarządu województwa przez sejmik województwa nowej kadencji, a w przypadku zarządu powiatu - na okres do lat 2, nie dłużej jednak niż do wyboru zarządu przez radę kolejnej kadencji. W każdym z tych przypadków należy wpierw przedstawić zarzuty organom gminy, powiatu i województwa oraz wezwać je do niezwłocznego przedłożenia programu poprawy sytuacji w danej j.s.t. Komisarza rządowego powołuje Prezes Rady Ministrów na wniosek wojewody, zgłoszony za pośrednictwem ministra właściwego do spraw administracji publicznej. Na ogół przyczyny braku skuteczności wykonywania zadań publicznych związane są z perturbacjami politycznymi lub nadmiernym zadłużeniem j.s.t. ${ }^{29}$ Należy podkreślić, ze szczególnie ta druga przyczyna wymaga powołania na zarządcę komisarycznego osoby przygotowanej merytorycznie do wykonywania swoich funkcji. Jak dotychczas polska administracja publiczna nie posiada korpusu osób, które poprzez swoje doświadczenie merytoryczne i znajomość finansów publicznych na szczeblu lokalnym mogłyby być wykorzystywane do wypełniania czasowo funkcji zarządcy komisarycznego. Decyzje nominacyjne komisarzy mają na ogół charakter polityczny i dotyczą osób związanych politycznie $\mathrm{z}$ aktualnie funkcjonującą koalicją polityczną.

6. Do kompetencji nadzorczych Prezesa Rady Ministrów należy również zaliczyć wyrażanie zgody na treść statutów gmin powyżej 300 tys. mieszkańców oraz województw ${ }^{30}$.

W sprawach ustrojowych samorządu Konstytucja RP w art. 169 ust. 4 stwierdza, że „ustrój wewnętrzny jednostek samorządu terytorialnego określają w granicach ustaw ich organy stanowiące”. W praktyce jednak samorząd terytorialny ma niewielkie możliwości decydowania o kształcie swego ustroju, ponieważ usta-

29 W dotychczasowym stanie prawnym zadłużona gmina nie mogła zbankrutować. 12 czerwca 2018 r. rząd przyjął projekt ustawy „o szczególnych rozwiązaniach dotyczących gminy Ostrowice w województwie zachodniopomorskim”. W grudniu 2017 r. zadłużenie gminy wynosiło 437,3\% planowanych dochodów. W styczniu 2016 r. wprowadzono w Gminie Ostrowice zarząd komisaryczny. Projekt przyjęty przez rząd przewidywał, że Gmina Ostrowice przestanie istnieć 1 stycznia 2019 r., jej mienie przejdzie na Skarb Państwa, a gminy, do których terytorium Ostrowic zostanie włączone, nie będą obciążone jej długami. Przejęte przez Skarb Państwa mienie zostanie nabyte lub nieodpłatnie użyczone gminom, do których zostaną włączone Ostrowice. Wierzyciele będą mogli zgłaszać swoje roszczenia wojewodzie zachodniopomorskiemu, a ten je zweryfikuje. Jeżeli odpowiedź wojewody dotycząca wysokości zobowiązań będzie negatywna, wierzyciele Ostrowic będą mogli skierować sprawę do sądu. Podaję za: R. Krupa-Dąbrowska, Gmina zadłużona po uszy, „Rzeczpospolita” 2018, $\mathrm{nr}$ z 19 czerwca, s. A14. Projekt ten został zmaterializowany poprzez uchwalenie w dniu 5 lipca 2018 r. ustawy o szczególnych rozwiązaniach dotyczących gminy Ostrowice w województwie zachodniopomorskim, Dz.U. z 2018 r., poz. 1432.

30 Wskazuję na to w: R. P. Krawczyk, Samodzielność w praktyce działania samorzq̨du terytorialnego oraz w orzecznictwie Trybunału Konstytucyjnego, [w]: R. P. Krawczyk, A. Borowicz, Aktualne problemy samorzadu terytorialnego po 25 latach jego istnienia, Łódź 2016, s. 52. 
wodawca w aktach rangi ustawowej wprowadził istotne ograniczenia w stosunku do największych gmin i województw, żądając zgody Prezesa Rady Ministrów na treść ich statutów. W gminach powyżej 300 tys. mieszkańców projekt statutu podlega uzgodnieniu z Prezesem Rady Ministrów na wniosek ministra właściwego do spraw administracji publicznej (art. 3 ust. 2 ustawy o samorządzie gminnym), a w art. 7 ustawy o samorządzie województwa z kolei wymaga się, aby statut województwa był uzgodniony z Prezesem Rady Ministrów. Trudno zrozumieć ratio legis ustawodawcy. Jeżeli uznano, że poziom służb legislacyjnych samorządu jest zbyt niski, to raczej takim brakiem zaufania należało kierować się w stosunku do małych gmin, a nie odwrotnie. Nie ma wątpliwości, że rozwiązanie to jest anachroniczne i naruszające zasadę samodzielności samorządu.

Normy bezwzględnie obowiązujące, wynikające z ustaw ustrojowych samorzą$\mathrm{du}$, stworzyły wzorce ustrojowe jednostek samorządu terytorialnego, praktycznie nie pozostawiając swobody samorządowi, mimo że ten jest tworzony dla realizacji lokalnych priorytetów i celów. W niektórych przypadkach ustawodawca posunął się jeszcze dalej, przyjmując tzw. statuty wzorcowe ${ }^{31}$.

Również w doktrynie prawa samorządowego krytycznie ocenia się przyznanie Radzie Ministrów w art. 4 u.s.g. prawa do tworzenia, łączenia, dzielenia i znoszenia gmin oraz do ustalania ich granic. Rozwiązań tych nie zaliczam wprost do kompetencji nadzorczych Rady Ministrów wobec samorządu terytorialnego, choć niewątpliwie mamy tu do czynienia z uprawnieniami władczymi, które są elementem nadzoru. Regulacja art. 4 ust. 1 u.s.g. jest istotnym odstępstwem od ustawowej formy tworzenia samorządu ${ }^{32}$ - można wręcz stwierdzić, iż jest to istotne wkroczenie w konstytucyjną oraz ustawowo zagwarantowaną samorządność gmin ${ }^{33}$. W świetle obecnych uregulowań postępowanie dotyczące granic terytorialnych gmin może być wszczynane na wniosek zainteresowanej gminy lub z inicjatywy Rady Ministrów. Ustawodawca nie określa, jakie przesłanki muszą być spełnione, aby Rada Ministrów mogła zainicjować takie postępowanie. Jak zwraca uwagę Trybunał Konstytucyjny w wyroku z dnia 4 listopada 2003 r., „przyczyna ta musi odpowiadać interesowi publicznemu, przemawiającemu - na poziomie ogólno-

31 Z taką sytuacją mieliśmy do czynienia w latach 1998-2001 wobec powiatu, gdzie na mocy rozporządzenia Ministra Spraw Wewnętrznych i Administracji z dnia 27 listopada $1998 \mathrm{r}$. w sprawie wzorcowego statutu powiatu (Dz.U. nr 146, poz. 957) stworzono wzór statutu dla powiatu. Akt ten został na szczęście uchylony z dniem 30 maja 2001 r. ustawą z dnia 11 kwietnia 2001 r. o zmianie ustaw: o samorządzie gminnym, samorządzie powiatowym, o samorządzie województwa, o administracji rządowej w województwie oraz o zmianie niektórych innych ustaw (Dz.U. z 2001 r., nr 45, poz. 479).

32 Z. Niewiadomski, W. Grzelczak, Ustawa o samorządzie terytorialnym z komentarzem, Warszawa 2005, s. 44.

33 Tak: P. Czachowski, A. Jaroszyński, S. Piątek, Prawo samorzq̨du terytorialnego. Przepisy z komentarzem, Warszawa 1997, s. 14; B. Dolnicki (red.), Ustawa o samorzqdzie gminnym. Komentarz, Warszawa 2010. 
krajowym - za zmianą granic konkretnych gmin"34. Niezależnie od rodzaju postępowania wspólne jest więc to, że konieczność dokonania zmiany „przeciwstawiana jest konstytucyjnej wartości, jaką jest stabilizacja stosunków polityczno-terytorialnych nie tylko w gminach, lecz w skali całego kraju - wyrażona przez art. 15 ust. 1 i 2 w związku z art. 2, art. 165 ust. 2 Konstytucji, zaś w przypadku gmin także poprzez art. 164 Konstytucji” ${ }^{35}$. Trybunał we wspomnianym wyżej wyroku stoi na stanowisku, że:

przyczyny wszczynania procedur korekcyjnych w obydwu postępowaniach muszą mieć zatem znamiona interesu publicznego. Tylko bowiem interes publiczny, a zarazem „zakotwiczony” w wartościach konstytucyjnie chronionych, może skutecznie konkurować z inną wartością konstytucyjnie chronioną w demokratycznym państwie prawa, jaką jest stabilizacja wewnętrznych stosunków polityczno-terytorialnych. [...] Samo zaś stwierdzenie, iż gmina wnioskująca powołuje się nie tylko na interes własny, lecz i interes publiczny o charakterze lokalnym, nie wystarczy jeszcze do uznania go za zasługujący na uwzględnienie przez Radę Ministrów. Musi być brana bowiem pod uwagę także sytuacja drugiej gminy, jaka powstałaby po dokonaniu zmian. Sytuacja tej gminy z reguły ulega pogorszeniu, co wynika $\mathrm{z}$ istoty tego rodzaju postępowania. Muszą jednak istnieć granice tego pogorszenia. Choćby bowiem powiększenie terytorium jednej gminy znajdowało swe uzasadnienie w wartościach konstytucyjnie chronionych, to przecież nie może to prowadzić do unicestwienia tożsamości drugiej gminy. Byłoby to bowiem w istocie jej faktycznym zniesieniem przy zachowaniu zewnętrznych pozorów utrzymania jej podmiotowości. To zaś kłóciłoby się z istotą postępowania w sprawie zmiany granic gmin, nakreśloną przez ustawę o samorządzie gminnym ${ }^{36}$.

Oczywiście, trudno bronić stanowiska, że podział terytorialny kraju jest konstrukcją niezmienną. To oznaczałoby postawienie bariery dla zmian demograficznych i społecznych w państwie, wręcz byłoby hamulcem rozwoju ${ }^{37}$. Trybunał Konstytucyjny stoi jednak na stanowisku, iż art. 4a i 4 b ustawy o samorządzie gminnym oraz art. 3a i 3 b ustawy o samorządzie powiatowym ${ }^{38} \mathrm{w}$ sposób jasny i precyzyjny dookreślają zasady zmiany granic gmin i powiató $\mathrm{w}^{39}$. Z kolei w orzeczeniu z 14 grudnia $1999 \mathrm{r}^{40}$ Trybunał Konstytucyjny uznał, że kryteria dokonywania zmian granic województw jako największych jednostek muszą być szczególnie doprecyzowane i nie mogą być uregulowane identycznie jak kryteria zmiany granic gmin czy powiatów. Pomimo takiego stanowiska Trybunału trudno w świetle art. 15 Konstytucji RP nie zauważyć, że „zasadniczy podział terytorialny państwa uwzględniający więzi społeczne, gospodarcze lub kulturowe i zapewniający jednostkom terytorialnym zdolność wykonywania zadań publicznych określa ustawa”. Oznacza to, że decyzje

34 K 1/03 OTK-A 2003, nr 8, poz. 85.

35 Ibidem.

36 Ibidem.

37 Por. K. Byjoch, J. Sulimierski, J. Tarno, Samorząd terytorialny po reformie ustrojowej państwa, Warszawa 2000, s. 22.

38 Dz.U. z 2013 r., poz. 595, poz. 645.

39 Tak w orzeczeniu z dnia 5 listopada 2001 r. - U1/01, OTK ZU 2001, nr 8, poz. 247.

40 K 10/99, OTK ZU 1999, nr 7, poz. 162. 
o utworzeniu, zniesieniu, podziale lub połączeniu gminy powinny być wprowadzane drogą ustawową. Zastrzeżenia mogą dotyczyć również treści art. 4a ust. 3 u.s.g. Wydanie rozporządzenia przez Radę Ministrów w sprawie tworzenia, łączenia, dzielenia i znoszenia gmin wymaga zasięgnięcia przez ministra spraw wewnętrznych i administracji opinii zainteresowanych rad gmin. Gdyby jednak takiej opinii nie wyrażono, w terminie 3 miesięcy od dnia otrzymania wystąpienia o opinię wymóg zasięgnięcia opinii w świetle art. 4a ust. 3 wydaje się za spełniony. Jak się zwraca uwagę w doktrynie, wymóg ten jest sprzeczny z art. 5 Europejskiej Karty Samorządu Lokalnego (EKSL), a uzasadnianie takiego postepowania przez TK względami technicznymi i sprawnościowymi wydaje się niewystarczające ${ }^{41}$. W dotychczasowej praktyce mieliśmy wyłącznie do czynienia z tworzeniem i dzieleniem gmin - zmiany terytorialne odnosiły się przeważnie do wyłączenia ze struktury terytorialnej jednej gminy fragmentu jej terytorium i przyłączenia do innej lub stworzenia dwóch nowych jednostek ${ }^{42}$. Nie było przypadków likwidacji na podstawie rozporządzenia Rady Ministrów gminy i włączenia całego jej terytorium do innej gminy. Sytuacja taka jest niewątpliwie bardziej skomplikowana, tym bardziej, iż można liczyć się z tym, że decyzja taka podyktowana będzie niemożliwością wykonywania zadań publicznych. Powstaje pytanie, która rada gminy zechce wydać pozytywną opinię, jeżeli jednocześnie gmina przejmująca będzie musiała spłacać zobowiązania gminy przejmowanej. W świetle tez, jakie zaprezentował TK w wyroku z 4 listopada 2003 r. zmiana taka nie mogłaby być dokonana w drodze rozporządzenia Rady Ministrów. Jeżeli przyjąć sposób rozumowania TK, to zmiana granic gmin może mieć charakter „szczegółowych korekt” i wówczas dopuszczalne jest rozporządzenie Rady Ministrów oraz może dojść do łączenia gmin w jedną większą terytorialnie jednostkę i w tym przypadku rozporządzenie nie może być aktem skutkującym zmianą zasadniczego podziału terytorialnego państwa ${ }^{43}$. W tym drugim przypadku winno to nastąpić $\mathrm{w}$ formie ustawy ${ }^{44}$. W jednym $\mathrm{z}$ orzeczeń TK, niestety, stwierdził, że likwidacja gminy nie stanowi naruszenia obywatelskiego prawa do samorządu, ponieważ obywatel od razu zostanie przypisany do innej gminy ${ }^{45}$. Jak wskazuje M. Kulesza, Trybunał Konstytucyjny nie rozróżnia między wielkimi reformami strukturalnymi

41 Tak: L. Kieres, Analiza zgodności polskiego prawa samorządu terytorialnego z Europejska Kartą Samorządu Terytorialnego, „Samorząd Terytorialny” 1998, nr 9, s. 50.

42 W 2015 r., pomimo negatywnej opinii Rady Gminy, z gminy Kamienica (powiat limanowski, woj. małopolskie) wyodrębniono nową gminę Szczawa z budżetem ok. $7 \mathrm{mln}$ zł, uniemożliwiającym wykonywanie zadań publicznych.

43 Tak: A. Feja-Paszkiewicz, Ustalenie i zmiana granic gmin w orzecznictwie Trybunału Konstytucyjnego - wybrane problemy, „Przegląd Prawa i Administracji” 2010, nr 83, s. 21-47.

44 Taka sytuacja miała miejsce w przypadku likwidacji gmin warszawskich oraz gminy Wesota - patrz: art. 15 ustawy z dnia 15 marca 2002 r. o ustroju miasta stołecznego Warszawy, Dz.U. nr 41, poz. 361 ze zm. Likwidacja ta była przedmiotem postępowania przed TK, który uznał ją za zgodną z Konstytucją - K 24.02, „Samorząd Terytorialny” 2003, nr 7-8, s. 6-253.

45 Wyrok TK z dnia 7 grudnia 2005 r., Kp 3/05, OTK-A 2005, nr 11, poz. 131, także: LEX nr 257765. 
a przepisami umożliwiającymi silniejszym gminom łatwe dokonywanie zmian granic $^{46}$. Dotychczas TK zaledwie raz zdecydował się w swoim orzeczeniu na zwrócenie uwagi ustawodawcy, że istnieje potrzeba stworzenia skutecznych mechanizmów prawnych zabezpieczających jednostki samorządu terytorialnego przed pochopnymi zmianami ich granic ${ }^{47}$. Jak wskazywałem powyżej na podstawie przypadku Gminy Kamienica (zob. przyp. 42), takich rozwiązań prawnych dotychczas nie przyjęto.

Również, jak wskazuje praktyka, Rada Ministrów nie dążyła do likwidacji gminy na podstawie rozporządzenia wskutek jej nadmiernego zadłużenia uniemożliwiającego prawidłowe wykonywanie zadań publicznych ${ }^{48}$. Brak stabilności ustroju finansowego j.s.t., wynikający z częstych zmian ustawy o finansach publicznych, niepotrzebnie naraża samorząd na większe ryzyko perturbacji finansowych, co może skutkować brakiem skuteczności w wykonywaniu zadań publicznych. $\mathrm{Na}$ marginesie należy zauważyć, że procedury, jakie przewidują ustawy samorządowe w stosunku do jednostek samorządowych wypełniających dyspozycję przepisów dotyczących wprowadzenia zarządów komisarycznych, nie nakładają na rząd obowiązku podejmowania decyzji w ciągu ustawowo wyznaczonego terminu. Praktyka, jaka w tym zakresie ma miejsce, pozwala na postawienie tezy, iż w takich przypadkach minister odpowiedzialny za sprawy administracji zwleka z przedstawieniem swojego stanowiska Prezesowi Rady Ministrów, a wobec organu składającego wniosek stosuje się rozwiązania nakładające na niego obowiązek przedstawiania kolejnych niepotrzebnych analiz i opinii ${ }^{49}$.

46 M. Kulesza, O tym, ile jest decentralizacji w centralizacji, a także o osobliwych nawykach uczonych administratywistów, „Samorząd Terytorialny” 2009, nr 12, s. 18-19.

47 Tak: postanowienie TK z 12 maja 2009 r., S 3/09, OTK-A 2009/5, poz. 75 w sprawie K. 37/06.

48 Taka sytuacja miała miejsce w przypadku gminy Ostrowice (woj. zachodniopomorskie). Wskutek zadłużenia sięgającego $211 \%$ wykonanych dochodów gmina była formalnym bankrutem. Gmina Drawsko Pomorskie nie była zainteresowana, by zostać beneficjentem tego połączenia poprzez przejęcie zadłużonej gminy - por. Czy dojdzie do bankructwa gminy, „Rzeczpospolita” 2015, nr z 18 sierpnia, s. C7. Należy podkreślić, że w praktyce występowały już przypadki przejmowania zadłużenia przez jeden z podmiotów przekształcanych, np. wyłączenie miasta Wałbrzycha z powiatu wałbrzyskiego i przywrócenie Wałbrzychowi statusu miasta na prawach powiatu. Miasto zadeklarowało przejęcie zobowiązań powiatu z tytułu kredytów i pożyczek łącznie na kwotę 34683362 zł. Patrz: pismo prezydenta Miasta Wałbrzycha (nr BOK 030.362011) z dnia 19 grudnia 2011 r. oraz opinia Regionalnej Izby Obrachunkowej z dnia 18 stycznia 2012 r. (sygn. GP-071-9/2/11/12) w kwestii skutków finansowych ewentualnego wyłączenia Miasta Wałbrzycha z powiatu wałbrzyskiego i przywrócenia Wałbrzychowi statusu miasta na prawach powiatu - cytowane dokumenty w zbiorach RIO Wrocław. Na marginesie należy zauważyć, że wcześniejsze połączenie samorządów z dniem 1 stycznia 2003 r. nastąpiło na mocy rozporządzenia Rady Ministrów z dnia 25 czerwca 2002 r. w sprawie połączenia miasta na prawach powiatu Wałbrzych z powiatem wałbrzyskim oraz ustalenia granic nowych powiatów, Dz.U. nr 93, poz. 821.

49 Wniosek wojewody zachodniopomorskiego informujący o niewypłacalności gminy Ostrowice został przedstawiony MSWiA w 2010 r.; wniosek wojewody tódzkiego i RIO w Łodzi w sprawie wprowadzenia zarządu komisarycznego w gminie Pątnów został przedstawiony 


\section{Santrauka}

\section{Ministras Pirmininkas prižiūri savivaldybę}

Pagal Lenkijos Respublikos Konstitucijos 171 str. 2 d. teritorinès savivaldos vienetų veiklos priežiūros organai yra Ministras Pirmininkas ir vaivadai, o finansinių reikalų srityje - regioninès auditorių rūmai. Konstitucinè formuluotė nustato subjektų, kurie gali veikti kaip teritorinès savivaldos priežiūros pareigūnai, katalogą. Konstitucinis savivaldos institucijų vadovų katalogas buvo uždarytas ir būtų nepriimtinas jo išplètimas įstatymu.

Priežiūros koncepcija Lenkijos teisinèje doktrinoje ir teisinejje sistemoje randama daugybę kartų - bet niekur mes negalime rasti išsamaus apibrèžimo. Atrodo, kad Lenkijos teisèje priežiūros sąvoka turètų būti grindžiama specialiomis priežiūros nuostatomis.

Atskyrimas, kaip bendrosios dviejų įstaigų priežiūros dalis: Ministras Pirmininkas ir Vaivadų pajègos, ịpareigoja apsvarstyti kiekvienos iš jų priežiūros taikymo sritị ir prioritetus.

Reikètų daryti prielaidą, kad Ministro Pirmininko priežiūros kompetencijos yra nurodytos atitinkamuose vietinès valdžios ịstatymų straipsniuose. Išskyrus jų taikymo sritị, kaip bendrosios priežiūros dalis, vaivadija išlieka kompetentinga priimti priežiūros sprendimus. Dabartinė teritorinès savivaldos priežiūros struktūra leidžia vaivadai, veikiančiam per viešojo administravimo tarnybą, prašyti Ministro Pirmininko atleisti savivaldybės merą ir paleisti rajono ar vaivadyjos administraciją. Tai gali atsitikti tais atvejais, kai savivaldybės meras, rajono ar vaivadijos administracija pakartotinai pažeidžia Konstituciją ar įstatymų nuostatas.

Šiuo atveju vaivadija privalo iškviesti savivaldybės merą, kad sustabdytų pažeidimus. Kai pažeidžiamoji institucija yra rajono ar vaivadijos administracija, vaivada ragina atsakingą instituciją imtis būtinų priemonių. Jei iškvietimas neturi poveikio, Ministras Pirmininkas gali atleisti savivaldybės merą arba nutraukti administracinę valdybą. Iki tol, kol bus išrinktas savivaldybės meras arba nauja valdyba, šią funkciją atlieka Ministro Pirmininko paskirtas asmuo. Ministro Pirmininko nutarimas dèl vykdomosios valdybos likvidavimo/atleidimo pasiekiamas tik įsigaliojimo data.

ministrowi w dniu 18 lutego 2010 r. - do momentu uprawomocnienia się rozstrzygnięcia nadzorczego Prezesa Rady Ministrów w dniu 5 marca 2013 r. upłynęło ponad trzy lata. Przyczyną złożenia wniosku było przekroczenie pułapu zadłużenia wyznaczonego przez ustawę o finansach publicznych. W dniu złożenia wniosku dług wynosił 7246 tys. zł, w dniu wprowadzenia zarządu komisarycznego ponad 18833 tys. zł. 


\section{Literatura}

Banaszak B., [w:] U. Kalina-Prasznik (red.), Encyklopedia prawa, wyd. II, Warszawa 2000. Banaszak B., Konstytucja Rzeczypospolitej Polskiej. Komentarz, Warszawa 2009.

Bar L., Elementy administracyjne w kierowaniu gospodarka narodowa, [w:] L. Bar (red.), Instytucje prawne w gospodarce narodowej (studia prawne), Warszawa 1981.

Boć J., Miemiec M., Organizacja prawna administracji, [w:] J. Boć (red.), Prawo administracyjne, Wrocław 1993.

Byjoch K., Sulimierski J.,Tarno J., Samorząd terytorialny po reformie ustrojowej państwa, Warszawa 2000.

Czachowski P., Jaroszyński A., Piątek S., Prawo samorzadu terytorialnego. Przepisy z komentarzem, Warszawa 1997.

Dawidowicz W., Zagadnienia ustroju administracji państwowej w Polsce, Warszawa 1970.

Dolnicki B., Samorząd terytorialny, Warszawa 2009.

Dolnicki B. (red.), Ustawa o samorzadzie gminnym. Komentarz, Warszawa 2010.

Feja-Paszkiewicz A., Ustalenie i zmiana granic gmin w orzecznictwie Trybunału Konstytucyjnego - wybrane problemy, „Przegląd Prawa i Administracji” 2010, nr 83.

Jeżewski J., [w:] Encyklopedia prawa, wyd. II, Warszawa 2000.

Kieres L., Analiza zgodności polskiego prawa samorzadu terytorialnego z Europejska Karta Samorząu Terytorialnego, „Samorząd Terytorialny” 1998, nr 9.

Kmieciak Z., Stahl M., Akty nadzoru nad działalnościa samorządu terytorialnego, „Samorząd Terytorialny" 2001, nr 1-2.

Krawczyk R. P., Samodzielność w praktyce działania samorządu terytorialnego oraz w orzecznictwie Trybunału Konstytucyjnego, [w]: R. P. Krawczyk, A. Borowicz, Aktualne problemy samorządu terytorialnego po 25 latach jego istnienia, Łódź 2016.

Krupa-Dąbrowska R., Gmina zadłużona po uszy, „Rzeczpospolita” 2018, nr z 19 czerwca.

Kulesza M., O tym, ile jest decentralizacji w centralizacji, a także o osobliwych nawykach uczonych administratywistów, „Samorząd Terytorialny” 2009, nr 12.

Leoński Z., Nadzór nad samorządem terytorialnym w świetle ustawy z 8 marca 1990 r., „Państwo i Prawo” 1990, nr 12.

Łętowski J., Szreniawski J., Kontrola administracji, [w:] T. Rabska, J. Łętowski, System prawa administracyjnego, t. III, Wrocław 1978.

Niewiadomski Z., [w:] Wielka encyklopedia prawa, red. nacz. B. Hołyst, wyd. II, Warszawa 2005.

Niewiadomski Z., Grzelczak W., Ustawa o samorzadzie terytorialnym z komentarzem, Warszawa 2005.

Pawłyta A., Samodzielność - pojęcie i granice, [w:] J. Sługocki (red.), Samorząd terytorialny w Polsce i w Europie. Doświadczenia i dylematy dalszego rozwoju, Bydgoszcz 2009.

Rybicki Z., Nadzór i kontrola, [w:] Z. Rybicki, S. Piątek, Zarys prawa administracyjnego i nauki administracji, Warszawa 1984. 
Służewski J., Nadzór i kontrola, [w:] T. Bocheński, S. Gebert, J. Służewski, Rady narodowe i terenowe organy administracji państwowej, Warszawa 1977.

Starościak J., Prawo administracyjne, wyd. V, Warszawa 1978.

Tarka M., Istota prawna nadzoru w gospodarce państwowej, Poznań 1990.

Wacinkiewicz D., Kontrola i nadzór w prawie komunalnym, Warszawa 2007.

Węgrzyn G., Rozwiązanie/odwołanie organów samorządu terytorialnego jako środek nadzoru, „Samorząd Terytorialny” 2007, nr 7-8.

Wierzbowski M., [w:] L. Jastrzębski, J. Lang, J. Służewski, M. Wierzbowski, Polskie prawo administracyjne, cz. I, Warszawa 1985.

Wróblewski J., Kontrola w państwie i jej aksjologia (pojęcia podstawowe), „Acta Universitatis Lodziensis. Folia Iuridica" 1981, nr 6.

\section{Akty prawne}

Konstytucja Rzeczypospolitej Polskiej z dnia 2 kwietnia 1997 r., Dz.U. z 1997 r., nr 78, poz. 483; z 2001 r., nr 28, poz. 319; z 2006 r., nr 200, poz. 1471; z 2009 r., nr 114, poz. 946.

Ustawa o samorządzie gminnym z dnia 8 marca 1990 r., Dz.U. z 2013 r., poz. 594 ze zm.

Ustawa o samorządzie powiatowym z dnia 5 czerwca 1998 r., Dz.U. z 2013 r., poz. 595 ze zm.

Ustawa o samorządzie województwa z dnia 5 czerwca 1998 r., Dz.U z 2013 r., poz. 596 ze zm.

Ustawa z dnia 11 kwietnia 2001 r. o zmianie ustaw: o samorządzie gminnym, samorządzie powiatowym, o samorządzie województwa, o administracji rządowej w województwie oraz o zmianie niektórych innych ustaw, Dz.U. z 2001 r., nr 45, poz. 479.

Ustawa z dnia 15 marca 2002 r. o ustroju miasta stołecznego Warszawy, Dz.U. nr 41, poz. 361 ze zm.

Ustawa z dnia 5 lipca 2018 r. o szczególnych rozwiązaniach dotyczących gminy Ostrowice w województwie zachodniopomorskim, Dz.U. z 2018 r., poz. 1432.

Rozporządzenie Ministra Spraw Wewnętrznych i Administracji z dnia 27 listopada 1998 r. w sprawie wzorcowego statutu powiatu, Dz.U. nr 146, poz. 957.

\section{Orzecznictwo Trybunału Konstytucyjnego i sądów administracyjnych}

Wyrok Trybunału Konstytucyjnego z dnia 14 grudnia 1999 r., K 10/99, OTK ZU 1999, nr 7, poz. 162.

Wyrok Trybunału Konstytucyjnego z dnia 5 listopada 2001 r., U1/01, OTK ZU 2001, nr 8, poz. 247.

Wyrok Trybunału Konstytucyjnego z dnia 4 listopada 2003 r., K 1/03 OTK-A 2003, nr 8, poz. 85.

Wyrok Trybunału Konstytucyjnego z dnia 7 grudnia 2005 r., Kp 3/05, OTK-A 2005, nr 11, poz. 131.

Wyrok NSA w Warszawie z dnia 10 października 2012 r., II SA/Wa 1329/12, LEX nr 1258346.

Wyrok NSA w Warszawie z dnia 5 marca 2013 r., II OSK 135/13, LEX nr 1340168.

Postanowienie Trybunału Konstytucyjnego z dnia 12 maja 2009 r., S 3/09, OTK-A 2009, nr 5. 